\title{
Practical Exploration of Undergraduate Talents Training Program Based on STEMA Innovative Model
}

\author{
Jie $\mathrm{He}^{1, \text { a }}$, Jinling Wei ${ }^{1, b}$, Wujian Yang ${ }^{1, \mathrm{c}}$, Zhike Han ${ }^{1}$ and Hui Jin ${ }^{2}$ \\ ${ }^{1}$ School of Information management, Zhejiang University Cit College, Hangzhou 310015, China; \\ ${ }^{2}$ School of electrical information, Zhejiang University Cit College, Hangzhou 310015, China; \\ ahej@zucc.edu.cn, cyangwj@zucc.edu.cn (correspondence author) \\ Keywords: STEMA model, Interdisciplinary technology applied, talents training, teaching reform
}

\begin{abstract}
As Zhejiang province released the Action Plan on "Made in China 2025", the universities and colleges all attempt to explore new kinds of education reforms in order to better serve the booming trends of the Zhejiang district economic development. On 2015, 42 universities have applied to turning into universities of applied technology so as to help increasing the district economic development and solving the social challenge. From a perspective view of College-Enterprise Cooperation and taking the specialty of Information Management and Information System as an example, this research reforms the interdisciplinary practical teaching system and contents, renews the teaching methods based on a new action learning way. and works out a new integrated undergraduate personnel training schema based on a new STEMA (Science 、 Technology、Engineering and Management-Arts ) model so as to provide some inspirations and references for the talent training of other universities of applied technology.
\end{abstract}

\section{Introduction}

China is advancing the trend of accelerating public entrepreneurship and innovation to help developing new economic growth so as to implement the industrial development outline of "Made in China 2025". In order to catch the opportunity of industrial transition and up-growth, Zhejiang province, at the same time, released "Made in China 2025 Zhejiang Action Outline", which will target at playing the key role of the future industrial field in China. By the year 2020, it has been estimated that the gross product of the innovation and high quality product industrial will exceeded 2000 billions RMB in China. Soon, on April 2015, Zhejiang State Development and Reform Commission、Zhejiang Department of Finance and Education released the ' Guidelines on transformation of higher education, which encourage more universities to focus on setting up more applied technology based specialty group. Finally, 42 universities have been successfully selected as technology applied ones over the next decade, such as the Zhejiang University City College (ZUCC for short), which is discussed as the case study in this research.

Early in the start-up period, as targeted at training technology applied undergraduate, ZUCC has accumulated lots of valuable strategies of cultivating technology-oriented talent by a series of methods, such as setting up the STEA model based theoretical teaching system、 constructing the school-enterprise cooperation model based talent cultivating schema 、 optimizing the interdisciplinary practical training contents and etc[2]. The college reduce the required courses and increase the electives, and provide the students with diversified modules for any specialty orientation with the purpose to fit for the students' requirement to become individualized learners and to construct a compound mode for knowledge and competence.

\section{The STEMA Model Based Theoretical and Practical Teaching Curriculum}

More and more technology teaching researchers have realized a factor that the number of people engaged in technology and engineering far exceeds those engaged in science and mathematics. On the contrary, most school education is more emphasis on science and mathematics. This contrast is particularly a problem in all over the world. Early in 1998, STEM[3] education originated in the USA. It supports broadening the study of engineering within each of the other subjects, and develop those soft skills like communication, problem solving, critical thinking, creativity, and data analysis. Most 
higher education in China have placed emphasis through reform and funding on STEM program as a fundamental part of the cultivating of skills like creativity for undergraduate. However, at its early stage in China, STEM based theoretical teaching system only mechanically combine the theoretical knowledge of different disciplines together without thinking how to put it into practical application.

ZUCC have already applied STEM on some of its specialties such as Information Management and Information System (IMIS for short) specialization[4]. Through one decade of STEM teaching reforming exploration, ZUCC has created a set of theory and practical teaching system with its own characteristics, which derived from STEM but have been refined into another model-STEMA. STEMA is a term that refers to the academic disciplines of science, technology, engineering and management-arts [5].

In order to avoid mechanical combination of different knowledge, ZUCC find a way which can flexibly integrated each subject and put all theoretical knowledge under a main clue-Practical Application Case (PAC for short). PAC combined different practical skills derived from different practical training courses and is closely designed toward the specific cultivating objectives of a certain skills training

During the long-term practice of specialization construction, IMIS has set up a curriculum based on Mr. Mintzberg's management triangular model, which is listed below as Fig 1.

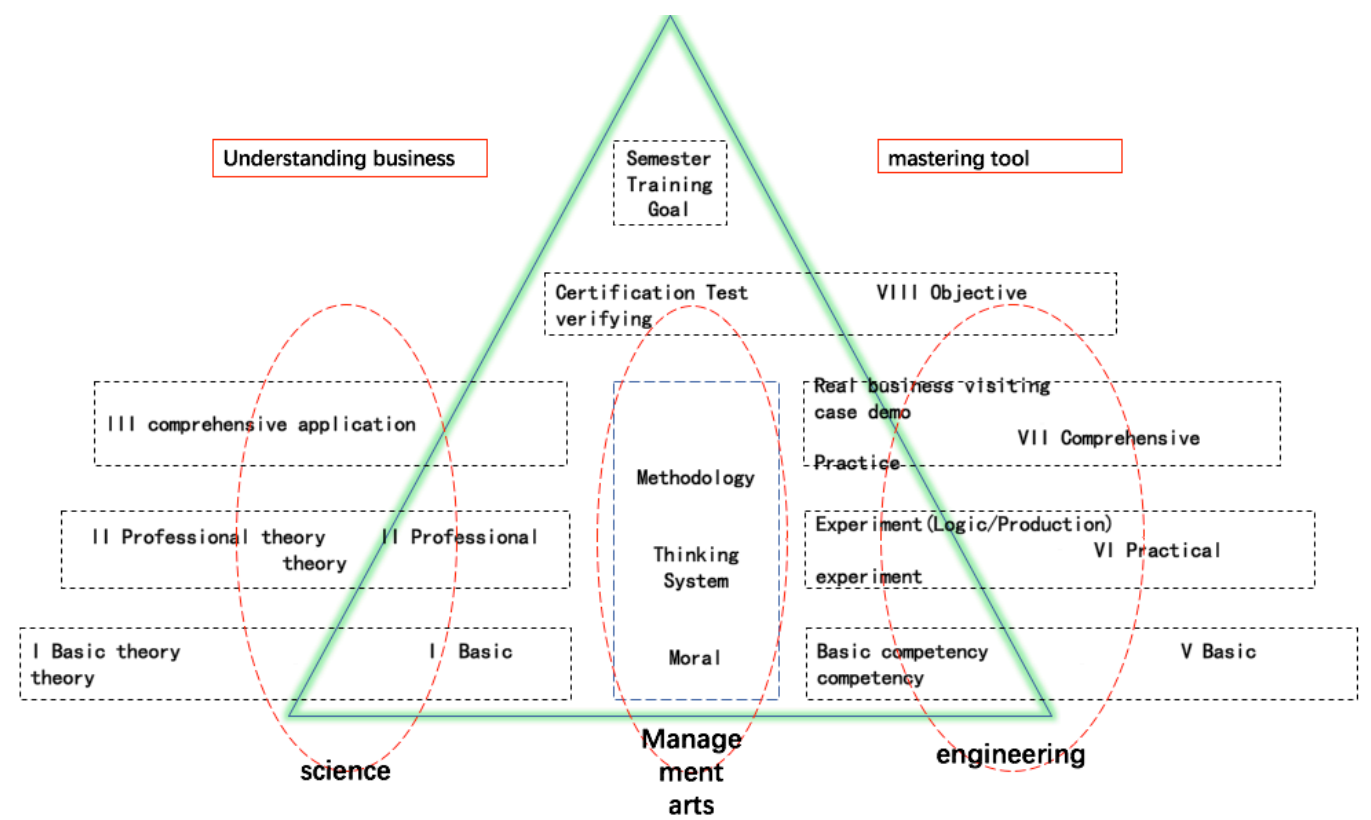

Fig. 1 Mintzberg's management triangular model

(1) Science(S): Using the knowledge to reasonably explain the relevant theory used by the production and operation of financial management activities. Such as ERP principles, financial accounting foundation, organizational design and process optimization.

(2) Technology(T): skillfully mastered the management software module operation. Capable of solving business problem by using management software. For example, ERP-U8 financial module, Supply Chain and Manufacturing modules, as well as project simulation training.

(3) Engineering(E): Through the action learning method to let the students form a team to participate in some simulation of real work projects, to solve some practical problems. For example, building enterprise business process, business simulation, participating in business development team, participate in the project team to develop their leadership skills so as to help organizations make more effective responses to change.

(4) Management-arts(MA): have the ability to adapt to job requirements in a real business environment and to solving the problem. For example, professional quality、communication skills; , speech and expression skills.

Above all, the STEMA model based theoretical and practical teaching curriculum focuses on the basis of student disciplines and professional theoretical knowledge and related experimental training 
in the first two years of professional planning, which is shown in stage I-stage III in Fig 1. While the stage IV is throughout the four years of learning process, which focusing on students ' quality intensive training, such as professional quality, communication skills, speech and expression skills and other personal soft skills.

\section{Establishing a School - Enterprise Cooperation based Model of Talents Cultivating}

To cultivate the applied technology talents for local economic development, college education is demanded to meet the new requirements for innovation talent training way which relies on the basis of school-enterprise cooperation. The development of social industry and enterprises cannot be separated from appropriate higher education with benign school - enterprise cooperation mode. In order to design a reasonable curriculum and set a clear training objective, higher education must understand the talents needs of enterprises so as to ensure that the curriculum offered by the school reflects both the current mainstream technology and the application of knowledge. In another word, the school-enterprise cooperation greatly contributes to the soft skill training of the undergraduate.

The new school-enterprise cooperation innovation lies in:

(1) promote integration among professional theory、 practice courses、 enterprise technology and business.

(2) construct trainee and employment-oriented based core competence practical training system.

(3) promote the exchange of talent between schools and enterprises.

The new school-enterprise cooperation is not only a training course which offered currently like theoretical course at fresh year and employment training course at senior year, or induction training courses offered by specific job-training company. Instead, the new cooperation offer the course which is designed by the reality requirements of the local enterprise. Thus, students have the opportunities to learn the knowledge and skill which is really needed by the reality world. To meet the requirements of production and research cooperation which in the service of local industrial development, IMIS has cooperated with the region's large information systems manufacturing enterprises (such as: UF company) for a long-term cooperation project of teaching and research. These large-scale information systems manufacturing enterprises represent advanced management ideas, excellent software design. From financial to sales, from production planning to human resource management, the cooperation covering all aspects of business management. While study in these kinds of school-enterprises cooperation, they gradually grasped the advanced industry knowledge, skillful software skills and rich experience in project management. Ultimately, they grow into information systems application engineers who is the urgent needed talent in the field of enterprise information management.

In ZUCC, school-enterprise cooperation based talent training model takes the UAP as developing teaching system which is one of the management software used in real business application, integrates the information application experience and enterprise resources of UF company derived from its more than 20 years of service for more than 180 enterprises in China. For long time of reforming research, ZUCC's talents training method offer an effective way.

\section{Establishing an Interdisciplinary Integration of Professional Curriculum System}

In order to let the student learning the skills along the problem solving in a real business context, the curriculum is designed along the sequential stages of project development. Thus, the learning of the core practical skill in different disciplinary course can be gradually mastered through the whole implementation of the project. For example, some of the professional course which is offered at the senior stage of the college is integrated with the product developing software platform so as to create a real business application for practical learning, listed as below. 
Table 1 The third Phase of Curriculum for IMIS Major

\begin{tabular}{|c|c|c|c|}
\hline No. & Name of the course & Teacher resources & remarks \\
\hline 1 & Modern production management & $\begin{array}{l}\text { Teachers from college, } \\
\text { interspersed with } \\
\text { business consultants }\end{array}$ & \\
\hline 2 & Principles and Applications of ERP & $\begin{array}{l}\text { Teachers from college, } \\
\text { interspersed with } \\
\text { business consultants }\end{array}$ & \\
\hline 3 & $\begin{array}{l}\text { Fundamentals of Enterprise Financial } \\
\text { Management Information }\end{array}$ & business consultants & $\begin{array}{l}\text { Mainly adopted UFIDA } \\
\text { ERP as teaching tool }\end{array}$ \\
\hline 4 & $\begin{array}{l}\text { Information Foundation and } \\
\text { Application of Enterprise Supply } \\
\text { Chain Management }\end{array}$ & business consultants & $\begin{array}{l}\text { Mainly adopted UFIDA } \\
\text { ERP as teaching tool }\end{array}$ \\
\hline 5 & Project management & & \\
\hline 6 & $\begin{array}{l}\text { Information system analysis and } \\
\text { development }\end{array}$ & & $\begin{array}{l}\text { Mainly adopted UFIDA } \\
\text { ERP as teaching tool }\end{array}$ \\
\hline 7 & $\begin{array}{l}\text { Application of Enterprise Financial } \\
\text { Management Information }\end{array}$ & business consultants & $\begin{array}{l}\text { Mainly adopted UFIDA } \\
\text { ERP as teaching tool }\end{array}$ \\
\hline 8 & Project simulation integrated training & business consultants & \\
\hline
\end{tabular}

The teaching course resources that supplied by the enterprise includes:

(1) after class micro-course: which is used for students to learn by themselves after class.

(2) tutoring resources: all courses are equipped with teacher counseling materials which help teacher to optimizing the teaching procedure so as to let them get the appropriately ways to ask question. use course resources and to interact.

\section{The Achievements for The STEMA Model Teaching Reforming}

After a long time, explorations of the STEMA model teaching, rich experiences have been accumulated under the cultivating schema of applied technology based undergraduate.

Firstly, the practical training information system used in a real business world is adopted by all practical courses, which can help the students to learn real information technology. Secondly multiple methods have been applied into the teaching procedure and teaching content. For example, course contents have been updated into new version of resources such as micro-class resources, action studying theory has been applied to teaching methods so as to inspire students to take the initiative to study and explore. Finally, running actual business operation are experienced by students through a variety of flexible teaching activities such as visiting factory participating in the company's business processes 、 solving the actual problem through computer-based tools.

Above all, students have learned and gradually acquired lots of skills such as programming v team cooperation 、 business communication and business plan writing. Some of them even successfully won the national project of college students innovation and entrepreneurship training program.

After a long period of STEMA model based innovative teaching reform, a creative schema of undergraduate talent training for applied technology colleges has been successfully established, which offering a new idea of cultivating technology-oriented talents by other similar colleges and universities.

\section{References}

[1] On Advancing the System of Talent Cultivation in Priority Areas of Manufacturing in China[J]. Educational Research, 2016.

[2] Biasutti M, Eldeghaidy H. Interdisciplinary project-based learning: an online wiki experience in teacher education[J]. Technology Pedagogy \& Education, 2015, 24(3):339-355.

[3] Sanders M. STEM, STEM Education, STEMmania.[J]. Technology Teacher, 2008, 68(4):20-26.

[4] Yang Y, Zhang S, Chen T. The impact of IT on curricula design of Information Management and Information System Doctoral Education in China[J]. Medical Physics, 2012, 38(8):4681-4688.

[5] Information on https://fas.org/sgp/crs/misc/R42642.pdf 